\title{
AKTIVITAS KESENIAN KOMUNITAS SARANG TARUNG
}

\author{
Fajar Nurul Hidayah \\ Fakultas Seni Rupa dan Desain ISI Surakarta \\ yayah.fafa@gmail.com
}

\begin{abstract}
This article is the result of research that discusses the Sarang Tarung community art activities. The focus of the problem under study is the meaning that encourages the Sarang Tarung community to perform art activities, also discusses the background of the community's establishment, and how their activities are. The research method used is ethnography with taxonomic analysis. Symbolic interactionism theory (Herbert Blumer) is used as a scalpel. Sarang Tarung seen through symbolic interactionism is a series of processes of formation of meaning that underlie them to carry out artistic activities. Through symbolic interactionism, it can be seen that the meaning of art activities for the Sarang Tarung community is a form of caring, and it can be seen that the Sarang Tarung community does not fully understand popular art, they are also part of young people who consume popular art trends. They assume that popular art is a form of solidarity that is capable of giving changes to the welfare of the lower classes. This assumption encourages them to carry out artistic activities and not just become passive consumers.
\end{abstract}

\section{Keywords: Art Activity, Symbolic Interactionism, Sarang Tarung Community, Meaning.}

\begin{abstract}
ABSTRAK
Artikel ini merupakan hasil penelitian yang membahas aktivitas kesenian komunitas Sarang Tarung. Fokus permasalahan yang diteliti adalah makna yang mendorong komunitas Sarang Tarung melakukan aktivitas kesenian, juga membahas bagaimana latar belakang berdirinya komunitas, serta bagaimana bentuk aktivitas mereka. metode penelitian yang digunakan adalah etnografi dengan analisis taksonomi. Teori interaksionisme simbolik (Herbert Blumer) digunakan sebagai pisau bedah. Sarang Tarung dilihat melalui interaksionisme simbolik merupakan serangkaian proses pembentukan makna yang mendasari mereka melakukan aktivitas kesenian. Melalui interaksionisme simbolik, dapat diketahui makna aktivitas kesenian bagi komunitas Sarang Tarung adalah bentuk rasa kepedulian, selain itu dapat diketahui bahwa komunitas Sarang Tarung tidak sepenuhnya paham tentang seni kerakyatan, mereka juga bagian anak muda yang mengkonsumsi tren seni kerakyatan. Mereka beranggapan bahwa seni kerakyatan adalah bentuk solidaritas yang mampu memberi perubahan pada kesejahteraan masyarakat kelas bawah. Anggapan tersebut yang mendorong mereka melakukan aktivitas kesenian dan tidak sekadar menjadi konsumen pasif.
\end{abstract}

Kata kunci: Aktivitas Kesenian, Interaksionisme Simbolik, Komunitas Sarang Tarung, Makna. 


\section{PENDAHULUAN}

Aktivitas komunitas anak muda saat ini senantiasa membawa warna baru dalam dunia seni rupa. Fenomena komunitas anak muda dalam dunia seni rupa cukup marak di Surakarta. Aktivitas yang mereka lakukan pun relatif sama, seperti membuat zine indie yang berisi artikel seni rupa atau liputan peristiwa kesenian (seni rupa), menerbitkan komik atau kompilasi karya dengan cara diperbanyak (foto copy) kemudian dipublikasikan, membuat kerajinan tangan (handmade craft), berkarya dan berpameran bersama, mengadakan pameran dan forum diskusi dengan menghadirkan seniman tamu sebagai pembicara (presentasi), diskusi antar komunitas, juga sharing ilmu melalui workshop (yang tidak hanya dihadiri oleh kalangan seni rupa namun juga diperuntukkan bagi masyarakat umum).

Mayoritas komunitas seni rupa yang tumbuh dan berkembang di Surakarta dipelopori oleh anak muda dan mengangkat tema-tema popular atau keseharian yang akrab dengan kehidupan mereka. Hanya ada beberapa di antaranya yang mencoba melakukan kritik baik sosial maupun politik melalui kekaryaan mereka. Mereka meng- gunakan lukisan, karya grafis, instalasi, karya eksperimental, mural, atau grafiti sebagai media ekspresi.

Sarang Tarung merupakan salah satu komunitas seni rupa di Surakarta yang dipelopori oleh sekumpulan anak muda juga. Namun mereka memiliki aktivitas yang agak berbeda dari komunitas seni rupa (anak muda) yang lain. Komunitas seni rupa yang dibentuk oleh Dwi Atmaja (Bara), Agung Setiyawan, Normanda Prana Citra Fana, dan Ikhwan Yulanda (Otong) pada 27 Desember 2013 ini tidak hanya beranggotakan anak muda dari disiplin ilmu seni rupa, namun juga dari beragam disiplin ilmu seperti sosiologi, musik, kriya seni, dan lainnya. Keberagaman latar belakang pendidikan tersebut membuat Sarang Tarung memiliki sudut pandang yang lebih kaya dalam menyoal suatu masalah atau peristiwa yang akan diaplikasikan dalam karya mereka.

Eksekusi gagasan-gagasan mereka dilakukan melalui kegiatan bersama di ruang publik melalui kerja kolektif yang organik. Tematema yang sering diangkat erat kaitannya dengan peristiwa sejarah (Tragedi 1965 dan peristiwa penculikan orang Mei 1998) serta kesejahteraan buruh dan petani. Per- 
formance art kemudian dipilih sebagai media berekspresi, sekalipun pada beberapa kegiatan mereka juga menggunakan seni grafis dan seni lukis.

Tidak hanya karya-karya rupa saja yang disajikan, namun juga karya musik, puisi, dan teater. Semua kegiatan mereka lakukan di ruang publik, seperti di jalan raya, boulevard kampus, Sriwedari, Ngar -sopuro, café, dan di sekitar Gla dak. Tujuan Sarang Tarung memilih ruang publik sebagai ruang berkesenian didasari pada semboyan seni untuk masyarakat. Aktivitas yang dilakukan lebih banyak mengajak masyarakat untuk berinteraksi secara langsung dengan kesenian, karena itulah mereka lebih sering melakukan performance art. Respon dari kegiatan yang mereka lakukan pun tidak hanya dari kalangan seni rupa, namun juga masyarakat dan aparat kepolisian. Bahkan tidak jarang, dari kegiatan yang mereka lakukan, mereka dilabeli kekiri-kiri an, komunis, radikal, atau militan oleh masyarakat (Wawancara Ikhwan Yulanda, 17 Februari 2015).

Terlepas dari aktivitas kesenian komunitas Sarang Tarung, individu-individu di dalamnya (Sarang Tarung) senantiasa mengusung se- mangat berkomunitas dalam aktivitas kesenian mereka secara individu. Seperti yang dilakukan Yulanda dalam mengangkat isu kesejahteraan buruh dan petani, isu lingkungan, dan pelanggaran hak asasi manusia dalam penciptaan karya lukisnya, Citra mengekspresikan isu-isu yang serupa melalui desain grafis yang diterapkan pada merchandise seperti kaos dan tote bag, sementara Bara produktif menciptakan lagu dan aktivitas sosial secara mandiri maupun bergabung dengan komunitas lain. Sarang Tarung tidak pernah membatasi individu-individu di dalamnya untuk beraktivitas di luar komunitas. Pola yang sangat organik ini membuat aktivitas mengalir, artinya mereka mampu merespon persoalan yang ada saat ini.

Aktivitas kesenian yang relatif berbeda dengan komunitas seni rupa di Surakarta (saat ini) membuat Komunitas Sarang Tarung menarik untuk diteliti lebih lanjut. Termasuk juga aktivitas individuindividu Sarang Tarung di luar komunitas yang masih membawa semangat dan gagasan yang sama, Penelitian ini perlu dilakukan untuk mengetahui gagasan apa yang mendasari aktivitas kreatif mereka dan apa makna aktivitas kreatif 
yang mereka lakukan. Maka, untuk menjawab kegelisahan-kegelisahan tersebut penelitian ini diarahkan pada bagaimana Aktivitas Kesenian Komunitas Sarang Tarung.

Penelitian berjudul Aktivitas Kesenian Komunitas Sarang Tarung ini dirumuskan dalam tiga poin pertanyaan, bagaimana latar belakang terbentuknya komunitas Sarang Tarung, bagaimana bentuk aktivitas kesenian yang dilakukan, dan bagaimana makna aktivitas kesenian bagi komunitas Sarang Tarung.

Penelitian tentang Aktivitas Kesenian Komunitas Sarang Tarung merupakan penelitian kualitatif dengan menggunakan pendekatan etnografi. Etnografi merupakan aktivitas mendeskripsikan kebudayaan dengan tujuan memahami pandangan hidup dari sudut pandang penduduk asli atau subjek yang diteliti (Spradley. 1997: 3). Penelitian etnografi mengkaji secara alamiah individu dan masyarakat yang hidup pada budaya tertentu (Jarwo \& Nur Hafid, 2013).

Penelitian ini menggunakan dua sumber data, sumber data primer dalam penelitian yang dilakukan adalah komunitas Sarang Tarung dan sumber data sekunder seperti Syaifudin Hafis (45 tahun), pendiri dan anggota KS3 yang sering terlibat dalam beberapa kegiatan dengan Sarang Tarung, Jejer Wadon, kelompok aktivis perempuan Surakarta yang aktif dalam pergerakan perempuan seperti diskusi, orasi, pembacaan puisi, dan membela hak-hak perempuan, Vera (27 tahun) selaku perwakilan LPH YAPHI, lembaga sosial yang bergerak dalam perlindungan hukum di Surakarta, Wahyu Eko Prasetyo (22 tahun), pengelola Ruang Atas yang pada tahun 2013 sempat mengelola Kepatihan Art Space, Usman Supardi (26 tahun), mahasiswa seni rupa murni ISI Surakarta yang pernah satu kontrakan dengan Sarang Tarung dan sering terlibat dalam aktivitas kesenian mereka, Farid Sugiharto (21 tahun), mahasiswa seni rupa murni ISI Surakarta yang sering terlibat dalam aktivitas komunitas Sarang Tarung salah satunya dalam antologi puisi even Deklarasi, Anggun (21 tahun), perwakilan koalisi BEM Surakarta yang terlibat dalam longmarch solidaritas untuk kendeng (2014) dan workshop sablon cukil di Dharmosito Wonogiri (2015) dan dokumen aktivitas kesenian yang dilakukan Komunitas Sarang Tarung, seperti foto kegiatan. Teknik penelitian yang digunakan da- 
lam penelitian etnografi ini antara lain observasi partisipatoris, wawancara mendalam, dan riset dokumen.

Sesuai dengan metode penelitian etnografi yang digunakan, untuk menganalisis data digunakan analisis taksonomi. Analisis taksonomi didefinisikan sebagai suatu pencarian bagian-bagian dari suatu kebudayaan dan hubungan berbagai bagian itu dengan keseluruhannya (Spradley. 1997: 200).

Penelitian dilakukan dengan mengurai bagian-perbagian secara detail dari aktivitas kesenian komunitas Sarang Tarung. Mulai dari munculnya dorongan mereka untuk beraktivitas seni (seni kerakyatan), bentuk aktivitas kesenian mereka, interaksi sosial dalam aktivitas kesenian, sampai ditemukannya makna yang mendasari mereka melaku -kan aktivitas seni kerakyatan.

Proses mengurai bagian-perbagian tersebut dilakukan dengan menggunakan interaksionisme simbolik (Herbert Blumer). Seperti yang pernah diungkapkan oleh Blumer bahwa manusia melakukan suatu hal karena ada makna atas hal tersebut bagi mereka. dimulai dari komunitas Sarang Tarung memaknai seni kerakyatan, kemudian muncul rasa keingintahuan untuk mencari informasi tentang seni kerakyatan dengan melakukan interaksi sosial dengan komunitas sebelum mereka (yang mengusung seni kerakyatan) baik secara langsung atau tidak, kemudian melalui pemahaman yang mereka peroleh dari berbagai sumber tersebut mereka modifikasi dalam aktivitas kesenian.

\section{PEMBAHASAN}

\section{Latar Belakang Terbentuknya Komunitas Sarang Tarung}

Sarang Tarung merupakan sa -lah satu komunitas seni (yang mengusung seni kerakyatan) di Surakarta. Komunitas Sarang Tarung awalnya bermarkas di sebuah kamar kos-kosan di Gang Kepoh no. 30 Petoran, Sekarpace, Surakarta. Berdirinya Komunitas Sa -rang Tarung diprakarsai oleh sekelompok perupa muda dan aktivis sosial. Mereka diantaranya adalah Dwi Atmaja (Bara), Nurmanda Prana Citra Fana (Citra), Ikhwan Yulanda (Otong), Nanang, Dan Agung Setiawan. Terbentuknya komunitas seni rupa yang berkonsep pada seni kerakyatan ini berawal dari aktivitas nongkrong dan melalui keterlibatan anggota dalam penyelenggaraan even kesenian bersama. 
Sebelum mereka (Bara, Nanang, Agung, Yulanda, dan Citra) memutuskan bersentuhan langsung dengan masyarakat, mereka telah banyak menggali informasi tentang praktik seni kerakyatan dari perupa maupun aktivis sebelumnya. Penggalian informasi juga dilakukan melalui sumber tertulis. Di Surakarta, mereka sering berdiskusi dengan Saifuddin Hafiz, seorang perupa dan aktivis yang sempat membuat komunitas seni kerakyatan pada tahun 1994 yaitu Kelompok Seniman Sejinah Surakarta (KS3).

Perjumpaan mereka tidak terputus pada pembukaan pameran kala itu; berlanjut pada proses berkesenian bersama. Tahun berikutnya, Mei 2013, Saifuddin Hafiz dilibatkan dalam pameran seni rupa Mei Mbulet. Keterlibatan Saifuddin Hafis dalam pameran tersebut lebih sebagai teman sharing sebelum kegiatan terlaksana dan sempat, pada beberapa kesempatan (dalam rangkaian acara pameran Mei Mbulet) membaca puisi dan orasi.

Pameran keliling kota Solo dengan mengangkat isu Mei 1998 tersebut tidak hanya menyajikan karya-karya seni rupa dua dimensi, namun juga karya instalasi, performance art, musik akustik, pemba -caan puisi, orasi, dan live painting.
Mei Mbulet yang diangkat sebagai judul pameran berusaha menghadir -kan informasi tentang tragedi Mei 1998 terkait kasus penculikan orang, kerusuhan, penjarahan, dan pelanggaran hak asasi manusia. Lokasi yang digunakan antara lain Night Market di Ngarsopuro, Car Free Day di jalan Slamet Riyadi, Sriwedari, "gapura kapal" Institut Seni Indonesia Surakarta, serta depan gedung Bank Indonesia di jalan Jendral Sudirman. Titik-titik strategis dipilih agar aktivitas kesenian yang mereka lakukan bisa melebur dengan masyarakat. Namun pernah sekali dalam satu bulan itu, Mei Mbulet diadakan di Kepatihan Art Space yang masih dalam lingkungan kampus jurusan seni rupa murni ISI Surakarta.

Pada 27 Desember 2013 akhirnya mereka memutuskan untuk mengukuhkan Sarang Tarung sebagai komunitas. Bertempat di sebuah rumah kos beralamatkan di Gang Kepuh no. 30 RT 01 / RW 09 Petoran, Jebres, Surakarta, deklara -si Sarang Tarung dilaksanakan. Dengan dideklarasikannya Sarang Tarung sebagai komunitas, mengantarkan mereka menjadi pelaku seni yang mengusung semangat aktivisme serta senantiasa membela suara rakyat. Dengan demikian 
tujuan dari aktivitas kesenian yang mereka lakukan tidak terlepas pada aksi kemanusiaan dan semangat perlawanan atas segala bentuk penindasan dan ketidakadilan yang melekat pada tubuh rakyat (Pernyataan Sarang Tarung dalam pengantar Antologi Puisi Kemul Sarung pada edisi deklarasi $27 \mathrm{De}$ sember 2013).

Dalam Komunitas Sarang Tarung tidak ada keanggotaan yang mengikat. Bagi mereka Sarang Tarung hanya ada di Surakarta, di luar itu anggota berdiri atas nama mereka masing-masing. Tidak ada istilah Sarang Tarung sebagai identitas atau tanda pengenal. Sarang Tarung adalah rumah atau wadah untuk berbagi informasi, demikian mereka memaknainya. Sarang Tarung awalnya memang dibentuk dalam format komunitas yang memiliki keanggotaan yang jelas, namun seiring berjalan format tersebut tidak berlaku dan menyisakan Bara, Otong, dan Citra yang merasa bahwa diri mereka adalah personil-personil Komunitas Sarang Tarung.

Komunitas Sarang Tarung memiliki semboyan Berdikari dan Berevolusi. Berdiri di atas kaki sendiri atau berdikari membuat Sarang Tarung bekerja cukup keras dalam masalah pendanaan sementara berevolusi pada semboyan Sarang Tarung dimaknai bagaimana sebuah aktivitas kesenian dapat diterapkan dimana saja, dalam berbagai bentuk untuk menyampaikan gagasan mereka. Berevolusi, berubah seiring perkembangan jaman dan terbuka akan banyak hal. Semboyan berevolusi membuat aktivitas kesenian (seni kerakyatan) mereka menjadi luwes, menyesuaikan dengan kondisi lapangan dan era mereka. Komunitas Sarang Tarung menyadari bahwa tidak mungkin melakukan aktivitas kesenian seperti LEKRA atau Bumi Tarung di era sekarang, karena sudah berbeda jaman, seni kerakyatan yang mereka hadirkan bukan lagi perlawanan, namun bentuk negosiasi atas apa yang mereka bela.

Dalam Sarang Tarung, semua aktivitas dan pengelolaan komunitas berjalan secara organik, struktur organisasi tetap ada meskipun tidak tertulis. Anggota bekerja sesuai dengan kapasitas mereka, saling mengisi ketika ada kekosongan. Komunitas Sarang Tarung juga tidak pernah mengharuskan setiap anggota untuk selalu terlibat dalam setiap aktivitas kesenian. Sistem kerja yang natural 
tersebut yang membuat Komunitas Sarang Tarung bisa bertahan sampai saat ini.

Pola kerja yang organik tersebut kemudian membuat mereka cenderung lebih fleksibel menyoal ruang berkesenian. Ruang publik yang erat hubunganya dengan masyarakat inilah yang menjadi pilihan bagi Sarang Tarung sebagai galeri atau tempat berkesenian mereka.

\section{Bentuk Aktivitas Komunitas Sarang Tarung}

Pada awal terbentuknya, komunitas Sarang Tarung sering megunakan Bengkel Seni Sarang Tarung sebagai ruang untuk beraktivitas, mulai dari pameran seni rupa, diskusi seni, musik, maupun teater. Aktivitas pertama mereka adalah even Deklarasi pada 27 Desember 2013; selebrasi atau perayaan kelahiran Sarang Tarung sebagai komunitas.

Even deklarasi diadakan selama dua minggu dengan berbagai susunan acara. 27 Desember adalah malam pembukaan aktivitas kesenian mereka di Bengkel Seni Sarang Tarung, sejarah awal aktivitas kesenian yang mereka lakukan. Dalam acara tersebut Komunitas Sarang Tarung tidak hanya menghadirkan karya-karya dari komuni- tas mereka sendiri, mereka juga melibatkan beberapa seniman muda dan senior untuk turut mengisi rangkaian acara.

Even deklarasi malam itu, komunitas Sarang Tarung berperan sebagai tuan rumah, karya musik akustik, pembacaan puisi, dan performance art dihadirkan dari seniman lain. Malam deklarasi merupakan momen dimana mereka mengukuhkan diri sebagai komunitas sekaligus membangun ruang berkesenian (Bengkel Seni Sarang Tarung). Akan tetapi rangkaian acara tersebut kurang tersusun dengan rapi, sehingga acara deklarasi tersebut tampak kurang begitu sakral sebagai sebuah momentum pengukuhan komunitas.

Pada Mei 2015 mereka berrencana mengadakan Mei Mbulet \#2 sebagai lanjutan Mei Mbulet \#1 yang telah dilakukan pada tahun 2013. Diadakannya Mei Mbulet \#2 ini diharapkan bisa membakar semangat berkesenian anggota Sarang Tarung dan pihak lain yang akan dilibatkan. Selain itu Mei Mbulet \#2 yang akan diadakan juga diharapkan akan lebih membawa dampak pada masyarakat dari pada even sebelumnya.

Proses perencanaan Mei Mbu let\#2 sudah dilakukan sejak April 
2015, namun setelah melewati buIan Mei even tersebut masih belum terealisasikan. Bertepatan dengan hajatan presiden Joko Widodo pada 10 dan 11 Juni 2015, rencana tersebut mereka realisasikan meski tanpa tagline Mei Mbulet\#2. Bukan postering yang mereka lakukan, namun mural berupa lettering tentang tuntutan untuk mencabut Undang Undang ljin Usaha Pertambangan (UU IUP). Aktivitas tersebut mereka lakukan di dinding bangunan samping kantor Solopos di jalan Adi Sucipto pada malam tanggal 11 Juni 2015. Sementara pada tanggal 10 Juni, sekitar pukul delapan pagi, Sarang Tarung bersama koalisi BEM Surakarta melakukan boikot jalan di rute highway yang dilalui tamu-tamu Joko Widodo dalam acara pernikahan putra sulungnya. Boikot jalan dilakukan masih atas dasar tuntutan pencabutan undangundang ijin usaha pertambangan (UU IUP). UU IUP dirasa menjadi senjata ampuh bagi investor-investor asing untuk menguasai sumber daya alam dan melakukan eksploitasi terhadap teritori petani (Wawancara dengan Bara via sms, pada 18 Juni 2015).

Salah satu bentuk aktivitas Komunitas Sarang Tarung bersama komunitas atau instansi lain diwujudkan dalam kerja kolektif memperingati hari buruh sedunia (May Day). Pada 1 Mei 2014 di bawah patung Slamet Riyadi, peringatan Hari Buruh Sedunia dengan mengusung tema "Malam Seribu Lilin untuk Marsinah" digelar oleh Komunitas Sarang Tarung ber -sama Saifuddin Hafis, Jejer Wadon LBH YAPHI, Persatuan Maha -siswa Hukum (Permahi) Surakarta, dan Serikat Buruh Manunggal Sejahtera (SBSM). Keterlibatan komunitas Sarang Tarung dalam even ini tidak begitu banyak, karena lebih pada koordinator lapangan dan tata artistik/ setting tempat kegiaatan, sehingga lebih banyak aktivitas di balik layar. Sebelum menggelar Peringatan Hari Buruh Sedunia "Malam Seribu Lilin untuk Marsinah", komunitas Sarang Tarung juga sempat terlibat dalam beberapa aktivitas bersama Jejer Wadon di Surakarta.

Salah satu aktivitas yang pernah mereka lakukan bersama adalah pada peringatan Hari Perempuan Internasional (HPI) yang jatuh pada 8 Maret. Tahun 2014, tepatnya pada Minggu, 9 Maret 2014, Sarang Tarung melakukan performance art di bawah patung Slamet Riyadi bersamaan dengan tibanya rombongan Jejer Wadon 
yang sebelumnya telah melakukan longmarch sepanjang jalan Slamet Riyadi. Kurang lebih sekitar pukul 10.30 performance art dimulai. Dalam performance art tersebut dua anggota Sarang Tarung beradu peran. Yulanda, berdandan seperti mafia dengan jas hitam dan topi, berusaha menarik Citra, yang berdandan perempuan, untuk duduk di kursi. Tubuh Citra kemudian diikat dengan tali dan mulutnya dibungkam, Yulanda dengan berang mencabik-cabik baju yang dikenakan citra. Adegan tersebut mennggambarkan pelecehan dan tindakan kekerasan pada perempuan. Women Trafficking adalah tema yang diangkat oleh Jejer Wadon dan Sarang Tarung dalam acara peringatan HPI waktu itu.

Selain aktivitas bersama komunitas lain dalam aksi kesenian, mereka juga kerap turun ke bawah (terjun langsung di masyarakat yang sedang mengalami konflik) misalnya keterlibatan Sarang Tarung bersama Lembaga Bantuan Hukum (LBH) Semarang dalam kasus penolakan tambang di gunung Kendeng yang akan digunakan sebagai pabrik semen oleh PT. Semen Indonesia. Aktivitas tersebut terangkum dalam Solidaritas untuk Kendeng yang melibatkan banyak komunitas dan instansi seperti koalisi BEM se Jawa Tengah, LBH Semarang, Komunitas Sarang Tarung, Serikat Pengamen Indonesia, dan gabungan kelompok teater dari Yogyakarta (Wawancara dengan Otong, 23 Juni 2015).

Agenda solidaritas untuk Kendeng yang digelar setelah seratus hari ibu-ibu Rembang melakukan protes juga dilakukan serentak di beberapa kota seperti Jakarta, Yogyakarta, Surabaya, Semarang, dan Makasar. Setelah aksi solidaritas untuk Kendeng di Surakarta, aksi selanjutnya diadakan di Rembang dan Semarang. Kurang lebih satu minggu Komunitas Sarang Tarung, bersama komunitas lain, memberikan workshop sablon pada masyarakat Rembang, pameran poster, dan pentas seni rakyat (berupa pertunjukan musik dan teater oleh Serikat Pengamen Indonesia, Yogyakarta, dan komunitas seni relawan).

Pada tanggal 16 sampai 17 Maret 2015 LBH Semarang mengadakan pameran dan lelang karya "Nguripi Kendeng" (menghidupi Kendeng) Menjaga Kelestarian Ling -kungan dan Kelestarian Pangan Nusantara. Aktivitas tersebut dilakukan sebagai bentuk solidaritas untuk masyarakat Kendeng yang 
tengah berjuang mempertahankan tanah mereka. Pameran dan lelang karya tersebut dibuka untuk umum, digelar di Taman Budaya Raden Saleh, Semarang. Dalam aktivitas ini komunitas Sarang Tarung mesumbangkan karya dalam lelang dan mengisi performing musik oleh Siasat (band aliran folk balada yang digawangi oleh Bara).

Pada tanggal 23 Juni 2015, Komunitas Sarang Tarung mengadakan workshop sablon cukil dan kepenulisan yang merupakan bagian dari acara seminar dan pengenalan hukum perlindungan anak dan kelestarian lingkungan dalam "Forum Anak dan Lingkungan" yang diselenggarakan oleh LBH YAPHI dan Paguyuban Sendang Bodro Sejati di Balai Pertemuan Dusun Darmosito, Desa Tirtoswara, Kecamatan Giriwoyo. Untuk membantu kelancaran aktivitas yang Komunitas Sarang Tarung lakukan, mereka menggaet BEM UMS, Gerakan Literasi Indonesia, dan Komunitas Malam Sastra Solo.

Melalui aktivitas tersebut Komunitas Sarang Tarung dan rombongan ingin menanamkan kesadar -an mendokumentasikan desa tempat tinggal mereka sejak dini, dimulai dari hal-hal kecil di sekitar mereka dengan cara menuliskannya dalam bentuk karya tulis maupun menggambarnya. Sehingga ketika kasus seperti yang mereka alami ini muncul mereka memiliki bukti yang cukup kuat tentang pendokumentasian desa tempat tinggal mereka.

Aktivitas kesenian tidak hanya terputus pada kegiatan komunitas dan kolaborasi dengan komunitas atau instansi lain. Semangat dalam berkomunitas senantiasa ada pada aktivitas masing-masing anggota, sehingga di luar aktivitas komunitas Sarang Tarung, para anggota tetap mengusung semangat berkesenian untuk rakyat.

Yulanda (Otong) misalnya, da -lam karya lukisnya kerap mengangkat isu buruh dan petani pada rentang tahun 2014-2015. Lukisan tentang penggusuran lahan pertanian untuk pusat perbelanjaan dan mal, kesejahteraan buruh pabrik, peralihan lahan pertanian menjadi pabrik semen, dan masih banyak lainnya. Kecenderungan ter -sebut tidak lepas dari aktivitas Otong bersama Komunitas Sarang Tarung. Di samping itu latar belakang Otong, yang berasal dari keluarga petani, juga turut mempengaruhi kecenderungan karyanya. 
Lain Otong lain pula dengan Citra. Citra yang sudah lebih dulu berkeluarga memiliki aktivitas kesenian yang berbeda. Art commodity, demikian aktivitas kesenian yang Citra lakukan dalam kesehariannya. Karya-karya grafis dengan mengangkat isu kesejahteraan buruh dan petani diaplikasikannya dalam bentuk merchandise seperti tote bag dan kaos.

Merchandise dipilih Citra sebagai salah satu media penyampai gagasan, di samping sebagai pemenuh kebutuhan (nafkah). Merchandise merupakan media seni rupa yang paling dekat dengan masyarakat, produk seni yang digunakan semua lapisan masyarakat. Sehingga merchandise bisa menjadi media yang efektif sebagai media penyampai gagasan selain postering dan performance art.

Selain aktif dalam bermusik Bara yang terkadang bekerja sebagai pengamen jalanan senantiasa menjalin hubungan dan jaringan dengan kelompok pengamen jalanan di Surakarta, Sragen, dan Madiun. Mengamen merupakan salah satu langkah untuk membaur dengan mereka yang di bawah. Dengan begitu Bara tidak sekadar datang dan seolah membawa solusi untuk kesejahteraan mereka. Namun menjadi bagian dari yang disebut "bawah" tersebut, dengan menjadi bagian mereka, Bara mencoba untuk memberi pemahaman terkait pengembangan potensi yang mereka miliki, memotivasi pengamen jalanan untuk bermusik (menciptakan lagu dan menyanyikannya). Ide-ide penciptaan lagu merespon realitas yang mereka (pengamen) alami. Proses pendekatan dan pemahaman tersebut cukup sulit dilakukan, mayoritas pengamen jalanan kurang percaya diri menyanyikan lagu yang mereka buat sendiri. Menumbuhkan rasa percaya diri tersebut cukup sulit dilakukan, belum lagi respon masyarakat pada pengamen jalanan yang sering kali dianggap sampah masyarakat. Aktivitasnya bersama kelompok pengamen sempat mendorong pengamen dari Sragen hingga Mojokerto untuk membuat album kompilasi menanggapi kebijakan PT. KAl tentang larangan pedagang asongan untuk berjualan di stasiun. Semua lagu dan proses rekaman sampai distribusi dilakukan secara mandiri oleh kelompok pengamen SragenMojokerto,

Semangat mengusung seni kerakyatan dalam aktivitas komunitas Sarang Tarung secara tidak 
langsung telah mendarah daging pada anggotanya. Karena itu, di luar aktivitas komunitas, mereka se -nantiasa membawa semangat seni kerakyatan.

\section{Makna Aktivitas Kesenian Komunitas Sarang Tarung}

Setelah melalui proses yang panjang, diawali dari bagaimana makna itu muncul dari komunitas Sarang Tarung melalui berbagai hal yang mereka pahami terkait seni kerakyatan, kesejahteraan masyarakat dan permasalahan mereka. Pemahaman yang mereka peroleh secara langsung atau tidak tersebut kemudian membuat mereka mencari tahu lebih dalam tentang aktivitas kesenian (seni untuk rakyat) melalui interaksi sosial yang mereka lakukan dengan komunitas maupun seniman yang melakukan aktivitas kesenian (seni untuk rakyat). Pengalaman dari interaksi tersebut digunakan komunitas Sarang Tarung sebagai acuan bagi mereka dalam beraktivitas.

Makna yang muncul dari inter -aksi sosial yang telah komunitas Sarang Tarung lakukan kemudian tidak serta mereka terapkan dalam aktivitas kesenian. Dari pemahaman atas berbagai hal tentang seni kerakyatan tersebut mereka melaku -kan proses penafsiran dan pemodifikasian. Baru setelah itu komunitas Sarang Tarung akan menerapkan hasil modifikasi tersebut pada aktivitas kesenian mereka sesuai dengan permasalahan yang terjadi di era mereka saat ini.

Aktivitas kesenian yang dilaku -kan komunitas Sarang Tarung dalam masyarakat selama ini termasuk turba, tapi berbeda dengan turba yang dilakukan LEKRA. Jika pada era '60-'70-an LEKRA secara terang-terangan membela kesejahteraan rakyat. Dalam turba pun mereka tidak bergerak sendiri, mereka melakukan kerja jaringan dengan komunitas atau instansi lain.

Melalui aktivitas tersebut biasanya komunitas Sarang Tarung tidak hanya melakukan riset tentang kondisi masyarakat, namun juga membantu masyarakat untuk mesuarakan suara mereka sendiri, dengan mempertemukan masyarakat kontra pabrik semen dengan teman-teman jurnalis dari Gerakan Literasi Indonesia, kemudian mendorong masyarakat untuk menulis artikel dan dimuat di surat kabar lokal. Mengajak masyarakat untuk sadar media, berbagi informasi melalui apapun. Bahkan melalui jejaring sosial yang akrab di kalangan anak muda. Termasuk anak muda 
di desa. Semakin banyak yang meinformasikan, semakin banyak yang akan tahu kondisi mereka.

Modifikasi dari aktivitas kesenian komunitas sebelum mereka ini pun terkadang dilakukan tanpa mereka sadari. Mereka melakukan aktivitas kesenian berdasarkan pan -dangan mereka bahwa seni kerakyatan itu membela kesejahteraan rakyat bawah dan salah satu upaya penghapusan kelas. Upaya itu akan terwujud jika mereka melakukan tindakan nyata sebagai penyambung lidah masyarakat kelas bawah maupun bekerja bersama untuk me -selesaikan konflik realitas masyara kat. Entah membawa dampak yang besar atau kecil, yang penting mereka sudah melakukan dan tidak berhenti pada cita cita semata.

Berdasarkan analisis di atas, dapat dilihat bahwa makna yang mendorong aktivitas kesenian komunitas Sarang Tarung selain rasa kepedulian dan bentuk solidaritas ju -ga didorong oleh kekaguman mere -ka pada tokoh-tokoh dan atau komunitas seni yang mereka idolakan (tokoh-tokoh yang mengusung seni kerakyatan). Kekaguman tersebut akhirnya membuat mereka berpikir bahwa seni yang baik adalah seni kerakyatan. Akhirnya mereka mulai mengkonsumsi simbol- simbol yang melekat pada seni kerakyatan.

Aktivitas kesenian yang dilaku -kan oleh komunitas Sarang Tarung termasuk dalam subkultur anak muda pasca autentik, dimana mereka menggunakan dua konsep subkultur yang sangat berkaitan yaitu bricolage dan homologi. Bricolage merupakan proses penataan ulang dan rekontekstualisasi atas berbagai simbol (yang sebelumnya sudah memiliki makna) untuk mengkomunitasikan makna baru (Chris Barker, 2009: 344). Aktivitas turba, tiga sama, performance art di ruang publik, karya seni lukis Otong yang mengangkat persoalan tergusurnya lahan pertanian oleh pembangunan, produk merchandise, lirik dan jenis musik, serta pemilihan nama komunitas merupakan bricolage symbol dalam proses pembentukan identitas komunitas mereka. Konsep bricolage yang dilakukan komunitas Sarang Tarung tidak hanya pada aktivitas kesenian, tapi juga pada simbol-simbol yang melekat dalam seni kerakyatan seperti, gaya berbusana, penolakan mereka pada produk kapital, keberpihakan mereka pada masyarakat kelas bawah, dan sebagainya. Simbol-simbol tersebut mereka tata ulang dan mengkondisikannya dengan situasi 
saat ini untuk memperoleh makna yang lebih segar. Bricolage yang mereka lakukan pun tidak sepenuhnya mengacu pada sumber yang asli (autentik). Sehingga korelasi bricolage yang membentuk gaya hi -dup dalam keseharian mereka sudah tidak seautentik makna sebelumnya, dan telah mengalami per -geseran.

Informasi dari berbagai sumber tentang seni kerakyatan tersebut kemudian mereka modifikasi dan membentuk perilaku serta gaya hidup keseharian mereka (homologi). Dalam keseharian, mereka tampak seperti orang-orang pergerakan yang menunjukkan keberpihakan pada rakyat bawah. Namun gaya yang tidak mengacu pada sumber yang asli (autentik) tersebut lebih disebut sebagai tiruan yang sebatas penglihatan (Chris Barker, 2009: 358-359). Tapi bukan berarti tidak ada makna dari tiruan yang sebatas penglihatan tersebut. Komunitas Sarang Tarung tidak sekedar meniru atau mengkonsumsi makna seni kerakyatan dari komunitas seni yang mereka rujuk. Tapi mereka juga menjadi konsumen aktif dengan memproduksi makna mereka sendiri dan melakukan aktivitas kesenian di tengah masyarakat.
Komunitas Sarang Tarung adalah sekumpulan anak muda yang berada di ruang dan waktu yang berbeda dengan komunitas se -ni yang menginspirasi aktivitas kesenian mereka. Sehingga mereka melakukan aktivitas kesenian dengan gaya mereka yang khas. Dalam satu waktu mereka terjun ke masyarakat dan menyatakan keberpihakan mereka pada masyarakat kelas bawah, melakukan mural dan postering di pinggir jalan, melakukan pelatihan kesenian pada masyarakat dengan pantauan aparat, tapi dalam konteks waktu yang sama mereka juga melakukan aktivitas yang kebanyakan dilakukan oleh anak muda seperti pergi keluar bersama teman-teman, hadir dalam acara pameran, mereka juga bekerja untuk memenuhi kebutuhan mereka. Mereka melakukan aktivitas kesenian, namun mereka juga tidak lupa bersenang-senang. Hal ini juga membuat aktivitas mereka tidak selalu turba, mereka juga pernah menggelar pameran di café, tidak hanya itu, pada beberapa kesempatan anggota Sarang Tarung juga terlibat dalam even solidaritas yang diadakan di lingkungan kampus. sehingga informasi dan gagasan yang ingin mereka sampaikan dapat diterima tidak hanya ma- 
syarakat kelas bawah, tapi semua lapisan termasuk kalangan akademisi. Aktivitas yang terkesan hura-hura tersebut secara tidak langsung mampu menggugah kepedulian orang yang hadir atas permasalahan yang terjadi di masyarakat. Bahkan tidak jarang beberapa audience yang hadir turut bergabung dalam aktivitas kesenian mereka berikutnya.

Simbol pada seni kerakyatan yang mereka hadirkan pada akhirnya terluruhkan, mengalami pergeseran dari yang asli (autentik). Hal ini karena komunitas Sarang Tarung tidak terlalu mendalam mempelajari dan memahami seni kerakyatan. Keterluruhan tersebut dapat dilihat pada bentuk aktivitas kesenian mereka. Misal dalam aktivitas kesenian mereka di masyarakat, tujuan dari aktivitas kesenian yang awalnya mengarah pada bagaimana mendorong masyarakat untuk kritis menyoal realitas permasalahan mereka melalui kesenian, akhirnya realitas permasalahan tersebut mereka hadirkan dalam bentuk aktivitas kesenian mereka, seperti dalam karya lukis, pemberian workshop, dan merchandise yang mereka produksi. Melalui beberapa aktivitas kesenian, peran masyarakat justru didominasi oleh komunitas Sarang Tarung.

Keterluruhan tersebut bukan berarti menghilangkan makna aktivitas kesenian dalam komunitas Sarang Tarung, keterluruhan tersebut justru membentuk identitas atau gaya mereka. Berangkat dari tren dan dimodifikasi menjadi gaya.

Makna aktivitas kesenian mereka memang tidak seautentis sebelumnya, tapi dengan gaya mereka yang khas tersebut mereka mam -pu membentuk identitas mereka sebagai bagian dari seni kerakyatan sekaligus konsumen tren seni kerakyatan itu sendiri.

\section{SIMPULAN}

Dari sekian banyak komunitas seni di Surakarta, komunitas Sarang Tarung adalah komunitas seni yang dipelopori oleh anak muda Surakarta dengan mengusung konsep seni kerakyatan. Bentuk karya komunitas Sarang Tarung erat kaitannya dengan keberpihakan mereka terhadap masyarakat kelas bawah. Sebagian besar aktivitas kesenian dilakukan di ruang publik, degan maksud agar gagasan mereka dapat tersampaikan ke masyarakat luas.

Aktivitas kesenian komunitas Sarang Tarung dalam seni kerakyatan mempunyai arti tersendiri ba- 
gi mereka sehingga mendorong me -reka untuk beraktivitas di ruang publik secara berkelanjutan. Makna tersebut muncul dari pikiran mereka terhadap berbagai hal dalam seni kerakyatan. Berbagai hal tersebut mereka peroleh melalui serangkaian proses pencarian baik melalui sumber langsung maupun tidak langsung. Kemudian mereka mencari tahu berbagai hal tentang seni kerakyatan tersebut dengan melaku -kan aktivitas kesenian yang mempertemukan mereka dengan berbagai orang yang memiliki gagasan serupa baik dalam kesenian atau bukan, menjalin interaksi sosial dengan komunitas seni sebelum mereka (yang mengusung konsep seni kerakyatan), bahkan dengan masya -rakat kelas bawah itu sendiri.

Pemahaman tentang seni kerakyatan yang diperoleh dari berbagai hal tersebut kemudian mereka saring dan modifikasi. Hasil dari modifikasi tersebut kemudian membentuk pribadi masing-masing anggota Sarang Tarung, seperti gaya berbusana, selera musik, keberpihakan pada masyarakat kelas bawah, penolakan terhadap produk capital, dan karya mereka yang sering mengangkat permasalahan masyarakat kelas bawah, pelanggaran HAM, dan eksploitasi alam.
Serangkaian proses tersebut membentuk makna aktivitas kesenian mereka, meskipun makna tersebut sudah tidak seautentik sebelumnya. Hal tersebut dikarenakan serangkaian informasi tentang seni kerakyatan yang diperoleh komunitas Sarang Tarung tidak semuanya diperoleh dari sumber yang asli (yang benar-benar paham atas seni kerakyatan sebagai bagian pergerakan). Sehingga makna yang dihasilkan pun mengalami pergeseran.

Aktivitas kesenian yang mereka lakukan sebatas tiruan di permukaan. Tapi bukan berarti tidak ada makna dari tiruan. Pada kenyataannya mereka juga melakukan aktivitas kesenian yang dulu dilakukan oleh komunitas sebelum mereka yang dijadikan rujukan. Mereka tidak sekedar mengkonsumsi makna namun menciptakan makna mereka sendiri dalam konteks ruang dan waktu yang berbeda, sehingga membentuk gaya bagi diri mereka sendiri yang memang tidak sama dengan yang asli. Namun proses modifikasi yang menciptakan gaya mereka sendiri menjadi khas. Dalam satu waktu mereka bisa sangat heroik menyatakan keberpihakan mereka pada masyarakat kelas bawah, dan di 
waktu yang sama dalam konteks yang berbeda mereka juga melakukan hal yang sama dengan yang dilakukan anak muda lain.

Makna aktivitas kesenian yang muncul kemudian tidak hanya sebatas kepedulian, tetapi juga menyatu dengan gaya hidup mereka. seni kerakyatan akhirnya tidak hanya dibawa dalam turba, performance art di ruang publik, tapi juga membawanya ke café, galeri, lingkungan kampus, yang justru memperluas ruang gerak mereka dalam menyampaikan gagasan me reka

\section{DAFTAR PUSTAKA}

Antariksa. Tuan Tanah Kawin Muda : Hubungan Seni Rupa Lekra 1950-1965. Yogyakarta: Yayasan Seni Cemeti.

Arbuckle, Heidi. 2010. Taring Padi: Praktik Budaya Radikal di Indonesia. Yogyakarta: LKiS.

Barker, Chris. 2009. Cultural Studies: Teori dan Praktik. Yogyakarta: Kreasi Wacana.

Bhakti Heriyanto. 2014. Kajian Tentang Karya Seni Grafis Komunitas Taring Padi di Yogyakarta Periode Tahun 2008-2012. Skripsi Tidak
Diterbitkan. Surakarta: Universitas Sebelas Maret.

FX Pracoyo. Bumi Tarung: Realis Sosialis di Era Politik sebagai Panglima. Jurnal Seni Artistika, Vol. 1, No. 1 JuniSeptember. 2011. Jakarta. Fakultas Bahasa dan Sastra Universitas Negeri Jakarta.

Hebdige, Dick. 2000. Asal-Usul dan Ideologi Subculture Punk. Yogyakarta: Buku Baik.

Ryana Andryana. 2013. Peranan Komunitas Taring Padi dalam Mengkritik Kebijakan Penambangan Pasir Besi di Kulon Progo. Skripsi Tidak Diterbitkan. Yogyakarta: Universitas Gajah Mada.

Spadley, James P. 1997. Metode Etnografi..Yogyakarta: Tiara Wacana.

Umiarso Elbadiansyah. 2014. Interaksionisme Simbolik dari Era Klasik hingga Modern. Jakarta: Rajawali Pers.

\section{INTERNET}

Ahmad Sujadi. 2014. Menaklukan Pedagang Asongan di Atas $K A$, (online), (http://www.kompasiana. com/sujadi/menaklukan-pedagangasongan-di-atas-

ka 54f9864ba3331176038b5262

diakses pada 12 Agustus 2015).

Danar Widiyanto. 2015. Pembangunan Pabrik Semen Giriwoyo Masih 'Masalah'. (online), (http:// krjogja.com/read/262644/pembang unanpabriksemengiriwoyomasihma salah.Kr, diakses pada 24 Juni 2015). 
Humaska, 2014. Pedagang Asongan Boleh Berjualan Asal Sesuai Aturan, dalam http://bumn.go.id/ keretaapi/berita/328/Pedagang.Aso ngan.Boleh.Berjualan, .Asal.Sesuai. Aturan. Diakses pada 12 Agustus 2015, pukul 12.53 WIB

Ita Nina Winarsih. 2013. Pedagang Asongan Dilarang Berjualan di Stasiun. (online), (http://www.republika.co.id/berita/nasional/jawabarat nasional/

Iwan Wijono, Sejarah Performance Art Indonesia. (online), (http:// www.jogjanews.com/sejarahperformance-art-indonesia/, diakses pada 15 November 2015).

Mahardini Nur Afifah. 2014. Lewat Lagu, Musisi Solo Kecam Impunitas. (Online), http://www.solo pos.com/2014/06/30/album-barulewat-lagu-musisi-solo-kecamimpunitas-516235. Diakses pada 26 November 2015

Parengkuh, Astuti. 2014. Peringatan Hari Buruh, Malam Seribu Lilin untuk Marsinah, (online). (http://www.jurnalperempuan.org/pe ringatan-hari-buruh-malam-seribulilin-untuk-marsinah.html, diunduh pada 2 Mei 2015).

Ulisah, Sri. 2014. Kasus Pegunungan Kendeng yang Terlupakan, (online). http://lpmgemakeadilan. com/2014/10/kasus-pegunungankapur-kendeng-yang-terlupakan/, diunduh pada 10 Oktober 2015, pada 8.32 WIB. 